\title{
Bacterial translocation markers in type 2 diabetes mellitus: their association with glycemic control and diabetic kidney disease in Egyptian patients
}

\section{ABSTRACT}

Background. The involvement of bacterial translocation in the pathogenesis of type 2 diabetes mellitus (T2DM) has been highlighted in recent years. The objective of the current study was to evaluate the potential impact of lipopolysaccaride-binding protein (LBP) and DNA translocation on glycemic control and progression to diabetic kidney disease in T2DM patients.

Material and methods. A total of 30 T2DM patients as well as $\mathbf{3 0}$ controls were included in a cross-sectional observational study. Plasma LBP levels were determined using an enzyme linked immunoassay. DNA translocation was assessed using polymerase chain reaction targeting 16SrNA gene.

Results. Plasma levels of LBP were significantly elevated in T2DM patients than in controls $(p=0.02)$. LBP level was significantly and positively correlated with fasting glucose level, glycated hemoglobin, C-reactive protein, albumin-creatinine ratio and negatively correlated with glomerular filtration rate. Receiver operating curve revealed that LBP with a cut off of $15.17 \mu \mathrm{g} / \mathrm{mL}$ succeeded to predict both glycemic control and diabetic kidney disease in T2DM patients. The bacterial

Address for correspondence:

Marwa Ahmed Meheissen

Medical Microbiology \& Immunology Department,

Faculty of Medicine, Alexandria University, Kartoum Square,

Azarita, Alexandria, Egypt

Phone: +2 03 4862506, +2 01005667342

Fax: +2 034862506

e-mail: marwa.meheissen@alexmed.edu.eg

Clinical Diabetology 2019, 8, 4, 195-204

DOI: $10.5603 /$ DK.2019.0014

Received: 04.03.2019

Accepted: 29.03.2019
16SrRNA was detected in almost all blood samples of T2DM patients $(28 / 30)$ and in about half $(16 / 30)$ of the control group ( $p<0.001)$.

Conclusion. Translocation products could trigger diabetes related complications. Future interventional work should target these products to reverse their effects. (Clin Diabetol 2019; 8, 4: 195-204)

Key words: type 2 diabetes mellitus, diabetic kidney disease, lipopolysaccharide binding protein, DNA translocation, bacterial translocation

\section{Introduction}

Type 2 diabetes mellitus (T2DM) is a metabolic disorder characterized by hyperglycemia, insulin resistance and systemic inflammation [1]. Several life-threatening complications are associated with T2DM [1]. Therefore, understanding the possible mechanisms involved in the pathogenesis of T2DM or its complications is of great value to prevent its progression. Recent data suggests a role of the gut microbiota in the induction of systemic inflammation and consequently the regulation of glucose metabolism [2].

Changes in gut bacteria, combined with increased intestinal permeability, stimulate bacterial translocation through the gut barrier; a previously unconsidered source of inflammation. Markers of bacterial translocation include bacterial 16srRNA DNA and lipopolysaccharide (LPS) [3]. Upon translocation into the bloodstream, LPS induces metabolic endotoxemia followed by low-grade systemic inflammation involving the release of pro-inflammatory cytokines, such 
as tumor necrosis factor (TNF), interleukin 1 (IL1), and interleukin 6 (IL6) [4].

LPS binds to LPS-binding protein (LBP), a plasma protein synthesized mainly by the liver, which facilitates the interaction between LPS and cellular targets. Binding of LPS to LBP is the first step in an inflammatory cascade [5].

Since LPS has a short half-life and its measurement in biologic fluids has several limitations, together with the relatively slow rise of $L B P$, which could serve to monitor the interaction between LPS and innate immune cells, LBP level has been suggested as a good clinical marker of effective metabolic endotoxemia [6, 7]. Several studies have demonstrated that increased circulating levels of LBP were associated with obesity, and T2DM [8-11].

An inflammatory component has been related to the complications of diabetes and diabetic kidney disease. The involvement of inflammatory process draws the attention of researchers to use immunosuppressants to prevent the development of albuminuria and kidney disease [11].

In this context, the influence of DNA translocation or LBP concentrations on glycemic control, and on the progression of diabetic kidney disease in T2DM was evaluated in the present study.

\section{Subjects and methods}

A total of 30 T2DM patients, recruited from the Outpatient Clinic of Alexandria Main University Hospital, Egypt were included in this cross-sectional observational study. Subjects were diagnosed as having T2DM according to the report of the Expert Committee for the Diagnosis and Classification of Diabetes Mellitus [12]. Another 30 non-diabetic healthy subjects served as a control group. Patients with type $1 \mathrm{DM}$, other metabolic diseases, liver or cardiac disease, portal hypertension, infectious diseases, psychiatric problems, and hematological or malignant disease were excluded from the study. Patients on anti-inflammatory drugs as glucocorticoids or those on antibiotic therapy during the last 3 months were also excluded. None of the control subjects were under medication or had evidence of systemic or metabolic disease. An informed written consent was taken from each subject before inclusion in the study. The study was approved by the Ethics Committee of Alexandria Main University Hospital, Egypt.

All subjects were subjected to the following:

\section{History taking and full clinical examination}

Demographic data as age and sex were recorded. Body weight and height were measured using standardized methods. Body mass index (BMI) was calculated. Blood pressure was recorded.

\section{Laboratory routine analyses}

\section{Sample collection}

Venous blood samples ( $5 \mathrm{~mL}$ from each patient) were collected. Sampling was done in the morning after an overnight fast. Fresh serum and plasma samples were used for chemical and hematological tests, while aliquots from frozen whole blood samples and plasma samples were stored at $-80^{\circ} \mathrm{C}$ for PCR and LBP testing respectively.

\section{Chemical and hematological analyses}

Routine chemical and hematological tests were performed using automated analyzers. Insulin resistance was calculated on the basis of the homeostasis model assessment of IR (HOMA-IR), using the following formula: $[$ HOMA-IR] $=$ (fasting insulin $(\mathrm{mU} / \mathrm{L}) \times$ fasting glucose $(\mathrm{mmol} / \mathrm{L}) / 22.5)$ [13]. Glomerular filtration rate (GFR) was estimated using CKD-EPI equation [14]. Moderately increased albuminuria was defined as two positive urine samples with urinary albumin-creatinine ratio (ACR) of 30-300 in the past 3 months [14].

\section{Measurement of plasma LBP}

Plasma level of LBP was determined by a commercially available double antibody sandwich enzyme linked immunosorbent assay (Assay kit Co., Ltd, USA) according to the manufacturer's instructions.

\section{Detection of bacterial DNA by polymerase chain reaction (PCR)}

Detection of bacterial DNA in patients' blood was performed using PCR targeting 16SrRNA gene present in all bacteria, $\beta$-galactosidase gene found in most $E$. coli, and glutamine synthase gene of Bacteroides fragilis (B. fragilis), using specific primers as previously described [15].

DNA extraction from whole blood samples was done using GENEJET whole blood DNA extraction kit (ThermoFisher SCIENTIFIC) according to the manufacturer's instructions.

Each PCR reaction consisted of $12.5 \mu \mathrm{L}$ master mix (DreamTaq Green PCR master mix $(2 \times), 25$ picomoles $/ \mu \mathrm{L}$ of the primer to be used, $5 \mu \mathrm{L}$ of extracted DNA and sterile deionized water to a final volume of $25 \mu \mathrm{L}$. PCR amplification reaction was carried out using Applied Biosystems 2720, thermal cycler in the following conditions: an initial denaturation step at $95^{\circ} \mathrm{C}$ for $3 \mathrm{~min}$, followed by $60^{\circ} \mathrm{C}$ for $45 \mathrm{sec}$, and $72^{\circ} \mathrm{C}$ for $10 \mathrm{~min}$. This was followed by 35 cycles of denaturation at $95^{\circ} \mathrm{C}$ for $45 \mathrm{sec}$, annealing at $60^{\circ} \mathrm{C}$ for $45 \mathrm{sec}$, extension at $72^{\circ} \mathrm{C}$ for $1 \mathrm{~min}$, and finally an extension step at $72^{\circ} \mathrm{C}$ for 10 min. PCR products were electrophoresed on $1 \%$ agarose gels (Bioline, UK) stained with ethidium bromide. 
A 100 bp DNA ladder (Thermo Fisher SCIENTIFIC) was used as a marker.

\section{Statistical analysis}

Data were analyzed using IBM SPSS software package version 20.0. Qualitative data were described using number and percent. Quantitative data were described using range, arithmetic mean, standard deviation and median. Appropriate tests were used to compare quantitative and qualitative variables between the two studied groups. For data correlation Pearson correlation coefficients was used. Receiver operating characteristics (ROC) curve analysis was done to determine the LBP cutoff point, which has the highest sensitivity and specificity. Significance of the obtained results was judged at the $5 \%$ level.

\section{Results}

\section{Study population characteristics}

The mean age of T2DM subjects was $53.3 \pm 6.95$ years. Twenty-two (73.3\%) subjects were females and eight $(26.7 \%)$ subjects were males. The mean age of the control group was $47.17 \pm 11.0$ with 23 males (76.7\%) and 7 females (23.3\%).

\section{Comparison of clinical and laboratory parame-} ters between diabetics and control group

The clinical and laboratory data of the study subjects are reported in Table 1.

\section{Results of bacterial translocation markers}

When investigating bacterial translocation markers, it was revealed that the mean LBP plasma level was significantly higher in patients with T2DM compared with control group $(19.25 \pm 12.69 \mu \mathrm{g} / \mathrm{mL}$ and $13.49 \pm$ $2.25 \mu \mathrm{g} / \mathrm{mL}$ respectively) $(\mathrm{p}=0.02)$ as shown in Table 1 .

Regarding 16SrRNA DNA, it was found that most of the T2DM cases (28/30; 93.3\%) had circulating DNA compared to about half of the control group (16/30; $53.3 \%)$, this difference was statistically significant $\left(\chi^{2}=12.273^{*}, \mathrm{p} \leq 0.001\right)$ (Figure 1).

None of the T2DM cases or the control group was positive for glutamine synthase gene of Bacteroides fragilis, or $\beta$-galactosidase gene of $E$. coli.

To exclude the effect of obesity, diabetic cases were further subdivided according to BMI into obese $(n=26)$ and non-obese $(n=4)$ group. Comparison of LBP plasma level and the presence of circulating DNA between the two groups demonstrated that the mean LBP level of the obese group was $20.36 \pm 13.16 \mu \mathrm{g} / \mathrm{mL}$ compared to $12.07 \pm 6.02 \mu \mathrm{g} / \mathrm{mL}$ in the non-obese group, with no statistically significant difference between the two groups $\left(Z^{U}=-1.403, p=0.161\right)$. Most of the obese $(92.3 \%)$ and all non-obese $(100 \%)$ had positive 16SrRNA DNA with no statistically significant difference between the two groups. $\left(\chi^{2}=0.33, \mathrm{p}=\right.$ $=1.0$ ). This finding supports the idea that obesity was not a major cause of the differences.

\section{Correlation of LBP with various clinical and laboratory parameters}

Circulating plasma LBP level was significantly and positively correlated with BMI $(r=0.342, p=0.008)$, waist circumference $(r=0.361, p=0.005)$, total cholesterol level $(r=0.470, p<0.001)$, LDL-C $(r=$ $=0.518, p<0.001)$, fasting glucose level $(r=0.343$, $p=0.007), \mathrm{HbA}_{1 c}(r=0.269, p<0.037), \operatorname{CRP}(r=0.585$, $p<0.001)$, and ACR $(r=0.320, p<0.013)$. On the other hand, there was a statistically significant negative correlation between LBP level and GFR $(r=-0.289$, $\mathrm{p}=0.025$ ) (Table 2).

Table 3 shows that the model is highly significant with $p$ value $<0.001,45 \%$ of the variability in LBP level could be explained by this model $\left(R^{2}=0.451\right)$. CRP was the only variable which is independently and positively associated with plasma LBP levels $(p=0.001)$. The higher the CRP level the higher the LBP; one $\mathrm{mg} / \mathrm{L}$ increase in CRP will increase the LBP by $0.215 \mu \mathrm{g} / \mathrm{mL}$ holding the other predictors constant (Table 3).

The diagnostic value of LBP for prediction of glycemic control, and diabetic kidney disease

ROC curves were plotted to evaluate the diagnostic value, in terms of area under curve (AUC), of LBP in prediction of glycemic control as well as diabetic kidney disease; the proposed threshold value (cutoff point) of LBP was $\geq 15.17 \mu \mathrm{g} / \mathrm{mL}$ (Figure $2 \mathrm{~A}-\mathrm{D}$ ).

Relation of DNA translocation and various clinical and laboratory parameters in diabetics and control subjects

Comparison of different study parameters between subjects with positive and negative circulating 16SrRNA DNA (whether diabetics or controls) was performed. The mean BMI values in diabetic patients who had circulating DNA $\left(34.68 \pm 4.48 \mathrm{~kg} / \mathrm{m}^{2}\right)$, was significantly higher than among controls $\left(29.69 \pm 3.27 \mathrm{~kg} / \mathrm{m}^{2}\right)$ ( $p \leq 0.001$ ). Similarly, the waist circumference's mean in diabetic patients who had circulating DNA (116.43 \pm $\pm 5.36 \mathrm{~cm}$ ) was significantly higher than in the other groups $(p=0.003)$.

Regarding the lipid profile, it was found that the mean values of triglycerides (181.32 $\pm 73.69 \mathrm{mg} / \mathrm{dL})$, cholesterol $(216.04 \pm 24.92 \mathrm{mg} / \mathrm{dL})$, LDL-C levels $(137.14 \pm 19.6 \mathrm{mg} / \mathrm{dL})$, in diabetic patients with circulating DNA, were significantly higher than in the other 
Table 1. Comparison between the two studied groups according to clinical and laboratory measures

\begin{tabular}{|c|c|c|c|c|}
\hline $\begin{array}{l}\text { Clinical and laboratory } \\
\text { parameters }\end{array}$ & $\begin{array}{l}\text { T2DM cases } \\
(n=30)\end{array}$ & $\begin{array}{l}\text { Controls } \\
(n=30)\end{array}$ & Test of significance & $p$ value \\
\hline \multicolumn{5}{|l|}{ BMI $\left[\mathrm{kg} / \mathrm{m}^{2}\right]$} \\
\hline Min.-max. & $26.29-42.96$ & $24.91-36.15$ & $Z U=-4.459^{*}$ & $<0.001 *$ \\
\hline Mean \pm SD & $34.79 \pm 4.36$ & $29.37 \pm 3.03$ & & \\
\hline Median & 35.15 & 28.05 & & \\
\hline \multicolumn{5}{|l|}{ Waist circumference $[\mathrm{cm}]$} \\
\hline Min.-max. & $109-127$ & $100-125$ & $t=3.611^{*}$ & $0.001 *$ \\
\hline Mean \pm SD & $116.0 \pm 5.43$ & $110.77 \pm 5.79$ & & \\
\hline Median & 115.0 & 109.5 & & \\
\hline \multicolumn{5}{|c|}{ Mean blood pressure [mm Hg] } \\
\hline Min.-max. & $80-113.3$ & $86.7-106.7$ & $\mathrm{t}=1.261$ & 0.212 \\
\hline Mean \pm SD & $101.27 \pm 7.71$ & $98.83 \pm 7.29$ & & \\
\hline Median & 103.3 & 101.7 & & \\
\hline \multicolumn{5}{|l|}{ TG $[\mathrm{mg} / \mathrm{dL}]$} \\
\hline Min.-max. & $90-371$ & $98-150$ & $z^{U}=-3.466^{*}$ & $0.001^{*}$ \\
\hline Mean \pm SD & $180.33 \pm 71.2$ & $126.03 \pm 14.59$ & & \\
\hline Median & 174.0 & 124.0 & & \\
\hline \multicolumn{5}{|l|}{ Total cholesterol [mg/dL] } \\
\hline Min.-max. & $176-272$ & $145-210$ & $\mathrm{t}=8.11^{*}$ & $<0.001$ * \\
\hline Mean \pm SD & $216.4 \pm 24.52$ & $173.63 \pm 15.27$ & & \\
\hline Median & 217.0 & 170.0 & & \\
\hline \multicolumn{5}{|l|}{$\mathrm{HDL}-\mathrm{C}[\mathrm{mg} / \mathrm{dL}]$} \\
\hline Min.-max. & $30-67$ & $41-60$ & $z^{U}=-3.47^{*}$ & $0.001^{*}$ \\
\hline Mean \pm SD & $43.3 \pm 8.69$ & $49.4 \pm 5.59$ & & \\
\hline Median & 42.0 & 50.0 & & \\
\hline \multicolumn{5}{|l|}{ LDL-C [mg/dL] } \\
\hline Min.-max. & $104.4-188.8$ & $66-131$ & $\mathrm{t}=-3.234^{*}$ & $0.002^{*}$ \\
\hline Mean \pm SD & $136.74 \pm 20.24$ & $99.0 \pm 15.75$ & & \\
\hline Median & 133.8 & 99.5 & & \\
\hline \multicolumn{5}{|l|}{ Fasting glucose [mg/dL] } \\
\hline Min.-max. & $78-571$ & $80-111$ & $Z^{U}=-5.836^{*}$ & $<0.001$ * \\
\hline Mean \pm SD & $236.87 \pm 114.03$ & $93.2 \pm 6.98$ & & \\
\hline Median & 215.5 & 93.0 & & \\
\hline \multicolumn{5}{|l|}{ Fasting insulin $[\mathrm{mLU} / \mathrm{mL}]$} \\
\hline Min.-max. & $5.21-52.2$ & $5.2-15.3$ & $z^{U}=-1.738$ & 0.082 \\
\hline Mean \pm SD & $14.7 \pm 8.77$ & $10.49 \pm 2.88$ & & \\
\hline Median & 12.0 & 11.1 & & \\
\hline \multicolumn{5}{|l|}{ HOMA-IR } \\
\hline Min.-max. & $1.7-23.6$ & $1.1-3.8$ & $Z^{U}=-5.829^{*}$ & $<0.001 *$ \\
\hline Mean \pm SD & $8.04 \pm 4.58$ & $2.39 \pm 0.63$ & & \\
\hline Median & 7.65 & 2.4 & & \\
\hline \multicolumn{5}{|l|}{$\mathrm{HbA}_{1 \mathrm{c}}(\%)$} \\
\hline Min.-max. & $6.2-13.3$ & $4.9-6.0$ & $Z^{U}=-6.663^{*}$ & $<0.001 *$ \\
\hline Mean \pm SD & $9.82 \pm 2.25$ & $5.33 \pm 0.28$ & & \\
\hline Median & 10.0 & 5.3 & & \\
\hline \multicolumn{5}{|l|}{$\mathrm{Hb}[\mathrm{gm} / \mathrm{dL}]$} \\
\hline Min.-max. & $13-17$ & $13-17$ & $t=-1.267$ & 0.210 \\
\hline Mean \pm SD & $14.76 \pm 1.09$ & $15.1 \pm 0.99$ & & \\
\hline Median & 14.7 & 15.0 & & \\
\hline
\end{tabular}


Table 1. (cont.). Comparison between the two studied groups according to clinical and laboratory measures

\begin{tabular}{|c|c|c|c|c|}
\hline $\begin{array}{l}\text { Clinical and laboratory } \\
\text { parameters }\end{array}$ & $\begin{array}{l}\text { T2DM cases } \\
(n=30)\end{array}$ & $\begin{array}{l}\text { Controls } \\
(n=30)\end{array}$ & Test of significance & $p$ value \\
\hline \multicolumn{5}{|l|}{ WBCs (cells/cmm) } \\
\hline Min.-max. & $6.3-12.26$ & $4.24-18.9$ & $Z^{U}=-4.288^{*}$ & $<0.001$ * \\
\hline Mean \pm SD & $8.76 \pm 1.73$ & $6.79 \pm 2.73$ & & \\
\hline Median & 8.35 & 6.29 & & \\
\hline \multicolumn{5}{|l|}{ Platelets (cells/cmm) } \\
\hline Min.-max. & $159-400$ & $184-369$ & $t=0.176$ & 0.861 \\
\hline Mean \pm SD & $261.5 \pm 57.29$ & $259.1 \pm 47.66$ & & \\
\hline Median & 252.5 & 248.0 & & \\
\hline \multicolumn{5}{|l|}{ ALT [U/L] } \\
\hline Min.-max. & $11-44$ & $11-29$ & $z^{U}=-0.423$ & 0.672 \\
\hline Mean \pm SD & $19.5 \pm 7.56$ & $19.1 \pm 4.39$ & & \\
\hline Median & 19.5 & 20.0 & & \\
\hline \multicolumn{5}{|l|}{ AST (U/L) } \\
\hline Min.-max. & $12-57$ & $11-28$ & $z^{U}=-1.312$ & 0.189 \\
\hline Mean \pm SD & $19.33 \pm 10.13$ & $19.07 \pm 4.40$ & & \\
\hline Median & 15.5 & 19.0 & & \\
\hline \multicolumn{5}{|l|}{ Serum albumin $[\mathrm{g} / \mathrm{dL}]$} \\
\hline Min.-max. & $2.9-4.5$ & $3.5-4.9$ & $t=-6.748$ & $<0.001^{*}$ \\
\hline Mean \pm SD & $3.47 \pm 0.45$ & $4.17 \pm 0.34$ & & \\
\hline Median & 3.45 & 4.1 & & \\
\hline \multicolumn{5}{|l|}{ Urea [mg/dL] } \\
\hline Min.-max. & $50-200$ & $12-45$ & $Z^{U}=-6.657^{*}$ & $<0.001$ * \\
\hline Mean \pm SD & $111.73 \pm 43.25$ & $22.3 \pm 9.11$ & & \\
\hline Median & 100.0 & 19.5 & & \\
\hline \multicolumn{5}{|l|}{ Creatinine [mg/dL] } \\
\hline Min.-max. & $0.9-3.0$ & $0.4-1.0$ & $Z^{U}=-6.459^{*}$ & $<0.001 *$ \\
\hline Mean \pm SD & $1.68 \pm 0.52$ & $0.74 \pm 0.18$ & & \\
\hline Median & 1.6 & 0.7 & & \\
\hline \multicolumn{5}{|l|}{$\mathrm{GFR}\left[\mathrm{mL} / \mathrm{min} / 1.73 \mathrm{~m}^{2}\right]$} \\
\hline Min.-max. & $27.41-131.0$ & $92.22-242.01$ & $z^{U}=-6.416^{*}$ & $<0.001 *$ \\
\hline Mean \pm SD & $62.64 \pm 22.98$ & $156.68 \pm 42.54$ & & \\
\hline Median & 60.7 & 155.9 & & \\
\hline \multicolumn{5}{|l|}{ ACR $[\mathrm{mcg} / \mathrm{mg}]$} \\
\hline Min.-max. & $22.8-8000.0$ & $10.0-30.0$ & & \\
\hline Mean \pm SD & $1506.4 \pm 1909.7$ & $21.37 \pm 5.48$ & $Z^{U}=-6.436^{*}$ & $<0.001 *$ \\
\hline Median & 835.0 & 22.5 & & \\
\hline \multicolumn{5}{|l|}{$\mathrm{ESR}[\mathrm{mm} / \mathrm{hr}]$} \\
\hline Min.-max. & $20-132$ & $10-23$ & $Z^{U}=-6.386^{*}$ & $<0.001 *$ \\
\hline Mean \pm SD & $60.23 \pm 32.35$ & $15.2 \pm 3.93$ & & \\
\hline Median & 69.0 & 14.5 & & \\
\hline \multicolumn{5}{|l|}{ CRP [mg/L] } \\
\hline Min.-max. & $4-90$ & $3-16$ & $Z^{U}=-4.557^{*}$ & $<0.001 *$ \\
\hline Mean \pm SD & $31.07 \pm 23.07$ & $10.07 \pm 3.76$ & & \\
\hline Median & 21.0 & 11.0 & & \\
\hline \multicolumn{5}{|l|}{$\mathrm{LBP}[\mu \mathrm{g} / \mathrm{mL}]$} \\
\hline Min.-max. & $4.14-63.04$ & $11.01-17.9$ & $Z^{U}=-2.323^{*}$ & $0.02 *$ \\
\hline Mean \pm SD & $19.25 \pm 12.69$ & $13.49 \pm 2.25$ & & \\
\hline Median & 16.44 & 12.62 & & \\
\hline
\end{tabular}

$\mathrm{t}$ - calculated value for Student $\mathrm{t}$-test; $\mathrm{Z}^{\mathrm{U}}$ - calculated value for Mann Whitney non-parametric test; * - statistically significant at $\mathrm{p} \leq 0.05 ; \mathrm{BMI}$ - body mass index; TG — triglycerides; HDL-C — high-density lipoprotein; LDL-C — low-density lipoprotein; HOMA-IR — homeostatic model assessment for insulin resistance; $\mathrm{HbA}_{1 \mathrm{c}}$ - glycosylated hemoglobin; CRP — C-reactive protein; $\mathrm{Hb}$ - hemoglobin; ALT — alanine aminotransferase; AST — aspartate aminotransferase; GFR - glomerular filtration rate; ACR - albumin/creatinine ratio; ESR - erythrocyte sedimentation rate; CRP - C-reactive protein; LBP — lipopolysaccharide binding protein 


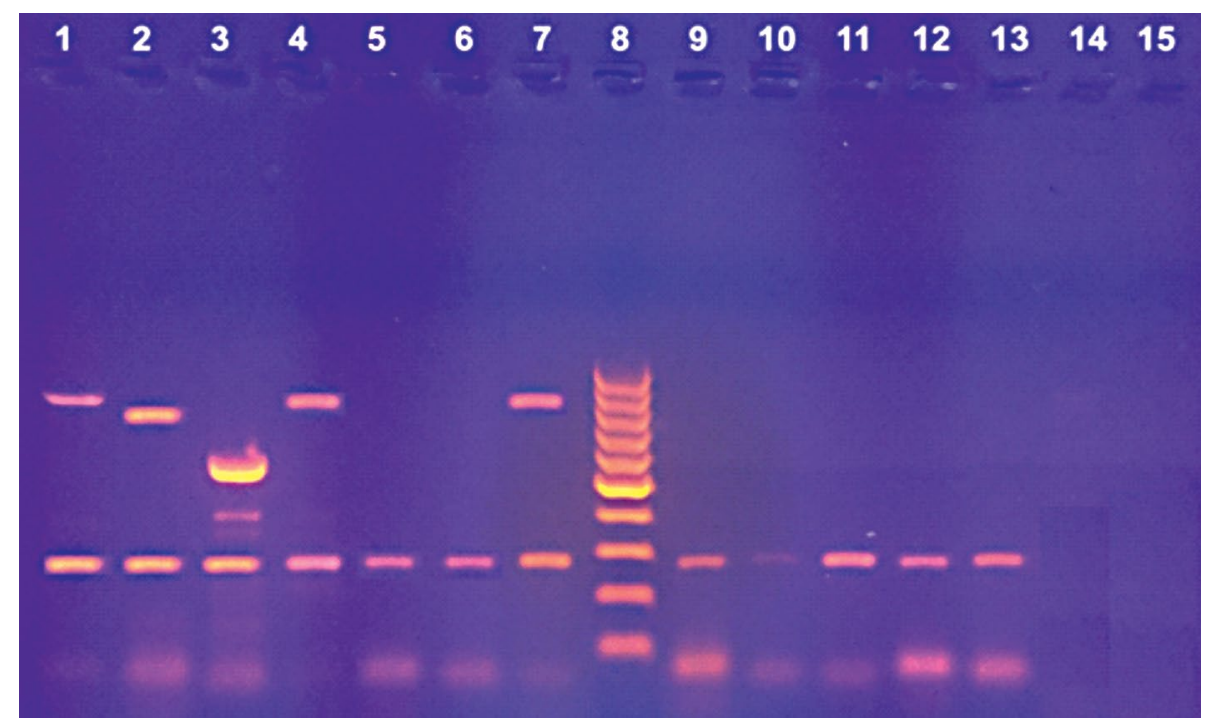

Figure 1. Agarose gel stained with ethidium bromide. A band of $798 \mathrm{bp}$ corresponds to bacterial broad range16SrRNA gene, a band of 762 bp corresponds to $E$. coli $\beta$-galactosidase gene (BG), a band of 581 bp corresponds to Bacteroides fragilis glutamine synthase (GS) gene, and a band of 268 bp corresponds to internal control $\beta$-globin gene. Lane 1: blood sample spiked with $E$. coli ATCC 25922; 16SrRNA gene positive control (798 bp). Lane 2: blood sample spiked with $E$. coli ATCC 25922; BG gene positive control (762 bp). Lane 3: blood sample spiked with Bacteroides fragilis ATCC 25285; glutamine synthase gene positive control (581 bp). Lane 4, 5, 6: Positive Blood sample (positive 16SrRNA gene in lane 4, negative BG gene in lane 5, negative GS gene in lane 6). Lane 7, 9, 10: Positive blood sample (positive 16SrRNA gene in lane 7, negative BG gene in lane 9, negative GS gene in lane 10). Lane 11, 12, 13: Negative blood sample for the three genes. Lane 14, 15: Negative controls. Lane 8: molecular size DNA marker (100-1000 bp)

groups ( $p=0.007 ; p \leq 0.001 ; p \leq 0.001$ respectively). Moreover, HDL-C mean $(42.32 \pm 7.67 \mathrm{mg} / \mathrm{dL})$ was significantly lower in diabetics who had circulating DNA ( $p=0.001)$.

In addition, diabetic patients with positive circulating DNA had significantly higher mean levels of fasting blood glucose (234.43 $\pm 117.76 \mathrm{mg} / \mathrm{dL})$, HOMA-IR score $(8.04 \pm 4.72), \mathrm{HbA}_{1 \mathrm{c}}(9.69 \pm 2.27 \%)$ than diabetics or controls with negative DNA translocation ( $p \leq 0.001, p=0.008, p \leq 0.001$ respectively).

The mean white blood cells count was the highest in diabetic patients with DNA translocation, while the mean serum albumin was the least in the same group. These differences were statistically significant $(p \leq 0.001)$. On the other hand, hemoglobin level, platelets count, ALT, and AST did not differ significantly between different groups.

The mean levels of urea $(1.68 \pm 0.54 \mathrm{mg} / \mathrm{dL})$, creatinine $(112.14 \pm 44.72 \mathrm{mg} / \mathrm{dL})$, albumin/creatinine ratio $(1556.88 \pm 1967.5 \mu \mathrm{g} / \mathrm{mg})$ were significantly higher in diabetic patients with circulating DNA when compared to control subjects with circulating DNA, or subjects who had no circulating DNA whether diabetics or non-diabetics $(p \leq 0.001)$. Also, the mean GFR in diabetic patients who had circulating DNA was significantly lower than in subjects who had no DNA whether diabetics or not $(p \leq 0.001)$.
Comparing the inflammatory markers between the four groups, revealed that the ESR $(59.32 \pm 33.32$ $\mathrm{mm} / \mathrm{hr})$ as well as the CRP $(31.93 \pm 23.66 \mathrm{mg} / \mathrm{L})$ mean levels in diabetics with circulating DNA were significantly higher than in the subjects with negative DNA translocation $(p \leq 0.001)$.

Although, the mean level of LBP was higher in diabetic patients $(19.41 \pm 13.14 \mu \mathrm{g} / \mathrm{mL})$ who had circulating DNA compared to controls $(14.03 \pm 2.19 \mu \mathrm{g} / \mathrm{mL})$ with circulating DNA, or diabetics and controls who had no DNA $(17.09 \pm 1.36 \mu \mathrm{g} / \mathrm{mL}, 12.87 \pm 2.24 \mu \mathrm{g} / \mathrm{mL}$ respectively), these differences were not statistically significant $(p=0.067)$.

\section{Discussion}

To our knowledge, this study is the first to examine the effect of endotoxemia and bacterial translocations on glycemic control or progression of diabetic kidney disease in an Egyptian population having T2DM.

The results of the anthropometric and laboratory parameters of the diabetic patients in the present study were similar to data obtained from previous studies [18-20]. Although several studies have investigated the association of LBP and other translocation markers with T2DM [8-11], few studies have focused on the association of LBP or DNA translocation and the progression of diabetes in type 2 diabetic patients. 
Tabela 2. Correlations of plasma LBP levels with various parameters

\begin{tabular}{lcc}
\hline Studied variables & \multicolumn{2}{c}{ LBP level } \\
\cline { 2 - 3 } & $\mathbf{r}$ & $\mathbf{p}$ value \\
\hline BMI & $0.342^{*}$ & $\mathbf{0 . 0 0 8 ^ { * }}$ \\
Waist circumference & $0.361^{*}$ & $\mathbf{0 . 0 0 5 ^ { * }}$ \\
Mean blood pressure & 0.117 & 0.375 \\
Triglycerides & 0.182 & 0.164 \\
Total cholesterol & $0.470^{*}$ & $<0.001^{*}$ \\
HDL-C & -0.229 & 0.078 \\
LDL-C & $0.518^{*}$ & $<0.001^{*}$ \\
Fasting blood glucose & $0.343^{*}$ & $\mathbf{0 . 0 0 7}$ \\
Fasting insulin & -0.166 & 0.204 \\
HOMA-IR & 0.088 & 0.503 \\
HbA ${ }_{1 c}$ & $0.269^{*}$ & $\mathbf{0 . 0 3 7}$ \\
Hb & -0.089 & 0.498 \\
WBCs count & 0.056 & 0.672 \\
Platelets count & -0.237 & 0.068 \\
ALT & -0.019 & 0.887 \\
AST & -0.065 & 0.623 \\
Serum albumin & -0.135 & 0.304 \\
Urea & 0.139 & 0.289 \\
Creatinine & 0.211 & 0.105 \\
GFR & $-0.289^{*}$ & $\mathbf{0 . 0 2 5 *}$ \\
ACR & $0.320^{*}$ & $\mathbf{0 . 0 1 3 ^ { * }}$ \\
ESR & 0.206 & 0.114 \\
CRP & $0.585^{*}$ & $<0.001^{*}$ \\
\hline & & \\
\hline
\end{tabular}

$r$ - Spearman correlation coefficient; * - statistically significant at $\mathrm{p} \leq 0.05$. BMI - body mass index; HDL-C - high density lipoprotein; LDL-C — low density lipoprotein; HOMA-IR — homeostatic model assessment of insulin resistance; $\mathrm{HbA}_{1 \mathrm{c}}-$ glycosylated hemoglobin; $\mathrm{Hb}$ - hemoglobin; ALT - alanine aminotransferase; AST - aspartate aminotransferase; GFR — glomerular filtration rate; ACR — albu$\mathrm{min} / \mathrm{creatinine}$ ratio; ESR - erythrocyte sedimentation rate; $\mathrm{CRP}$ - C-reactive protein

In the present study, the mean LBP level of the cases was significantly higher than that of the control group ( $p=0.02$ ). This was in agreement with a previous study, which examined the associations between intestinal permeability and T2DM, LBP was significantly higher in type 2 diabetic patients in comparison with normal individuals [19]. Similarly, Gubern et al., verified higher LBP concentration in T2DM patients and subjects with impaired glucose tolerance compared with non-diabetic subjects [20]. Also, Moreno-Navarrete et al., found that type 2 diabetic patients have higher levels of LBP than controls [9]. On the other hand, Zhou et al., conducted a 5-year nested case-control study on 3510 individuals from the Chinese population. Based on the results of their study, there was no significant difference in LBP levels at baseline between T2DM subjects and controls when matched for age, gender, and BMI. In addition, no association was
Tabela 3. Multiple linear regression analysis of factors affecting LBP level

\begin{tabular}{lccc}
\hline Studied variables & \multicolumn{2}{l}{ LBP level } & \\
\cline { 2 - 4 } & $\mathbf{B}$ & $\mathbf{t}$ & $\mathbf{p}$ \\
\hline BMI & 0.249 & 0.817 & 0.418 \\
Waist circumference & 0.032 & 0.152 & 0.879 \\
Cholesterol & 0.011 & 0.103 & 0.918 \\
LDL-C & 0.105 & 0.842 & 0.404 \\
FBG & -0.002 & -0.124 & 0.902 \\
HbA 1 c & -0.778 & -1.088 & 0.282 \\
GFR & -0.005 & -0.174 & 0.863 \\
CRP & 0.215 & 3.364 & $0.001^{*}$ \\
ACR & 0.0 & -0.336 & 0.738 \\
F (P) & \multicolumn{3}{c}{$4.558^{*}\left(<0.001^{*}\right)$} \\
R $^{2}$ & \multicolumn{3}{c}{0.451} \\
\hline
\end{tabular}

$B$ - regression coefficient; $t, p-$ calculated and $p$-value of t-test; $F(P)$ - calculated and $p$-value of ANOVA test; * - statistically significant at $\mathrm{p} \leq 0.05$

observed between serum LBP levels and the incidence of T2DM in the 5-year follow-up. They concluded that LBP on its own might not improve diabetes prediction [21].

In the current work, LBP was statistically significantly positively correlated with $\mathrm{BMI}$ and waist circumference in diabetic patients. It was also positively correlated with blood sugar level, $\mathrm{HbA}_{1 \mathrm{c}^{\prime}}$ total cholesterol, LDL-C, ACR and CRP. However, LBP was negatively correlated with GFR. Similarly, Kim et al., assessed LBP as a biomarker of obesity-related insulin resistance in adolescents, the results of their study showed LBP levels were significantly and positively associated with BMI [22]. Furthermore, circulating plasma LBP levels were significantly and positively associated with BMI, systolic blood pressure, aspartate aminotransferase, alanine aminotransferase, total cholesterol, LDL-C, fasting glucose and insulin, and insulin resistance in the study of Moreno-Navarrete et al. [9]. Serum LBP levels were also positively correlated with the parameters of obesity, insulin resistance, and inflammation in diabetic subjects as mentioned in a previous Japanese study [23]. In a prospective observational study involving 49 obese subjects undergoing bariatric surgery and 17 controls, plasma LPS was positively correlated with cardiometabolic risk factors, including triglycerides, systolic blood pressure, and $\mathrm{BMI}$ and was negatively correlated with HDL cholesterol [24]. Kim et al., found that plasma LBP levels were significantly and positively correlated with liver enzyme levels, a marker of liver damage and liver involvement in systemic inflammatory disease [22]. This observation was not encountered in our study where the LBP levels were not correlated with liver enzymes. 

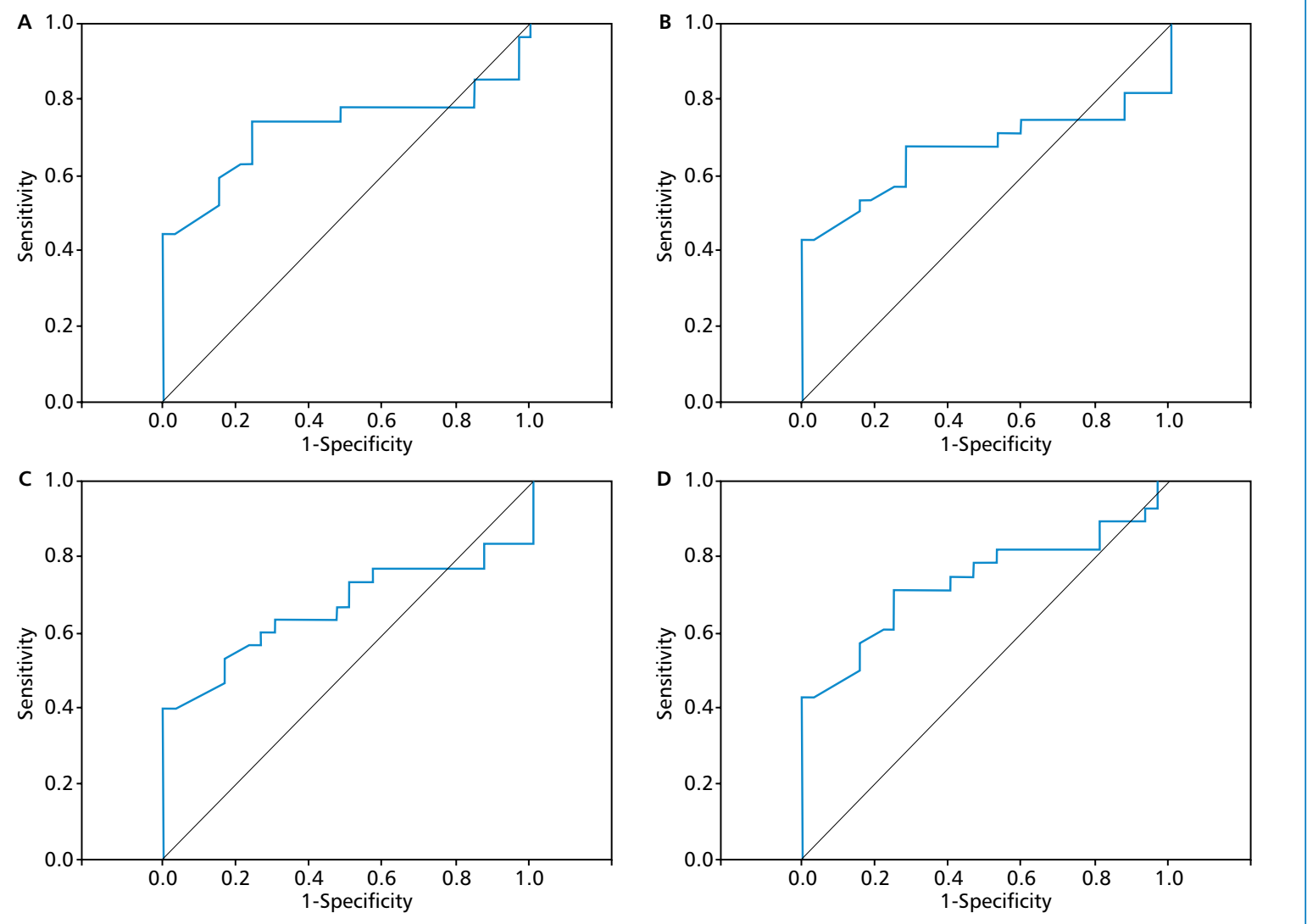

Figure 2A, B. ROC curves for LBP as a predictor of glycemic control in type 2 diabetes mellitus (A. FBG $\geq 126 \mathrm{mg} / \mathrm{dL}, \mathrm{B}$. $\mathrm{HbA} \mathrm{Ac}_{1 \mathrm{c}}$ $\geq 6.5$ ). A. Area under the curve (AUC): 0.723 , proposed threshold value: $\geq 15.17 \mu \mathrm{g} / \mathrm{mL}$, sensitivity: $74.1 \%$, specificity: $75.8 \%$, positive predictive value (PPV): $71.4 \%$, negative predictive value (NPV): $78.1 \%(p=0.003)$. B. AUC: 0.669 , threshold value: $\geq 15.17$, sensitivity: $67.9 \%$, specificity: $71.9 \%$, PPV: $67.9 \%$, NPV: $71.9 \%(p=0.025)$. C, D. ROC curves for LBP as a predictor of diabetic kidney disease (C. ACR $\geq 30 \mu \mathrm{g} / \mathrm{mg}, \mathrm{D}$. GFR $\geq 90 \mathrm{~mL} / \mathrm{min} / 1.73 \mathrm{~m}^{2}$ ). C. AUC: 0.664 , proposed threshold value: $\geq 15.17 \mu \mathrm{g} / \mathrm{mL}$, sensitivity: $63.3 \%$, specificity: $70.0 \%$, PPV: $67.9 \%$, NPV: $65.6 \%(p=0.029)$. D. AUC: 0.738 , threshold value: $\geq 15.17 \mu \mathrm{g} / \mathrm{mL}$, sensitivity: $71.4 \%$, specificity: $75.0 \%$, PPV: $71.4 \%, N P V: 75.0 \%(p=0.002)$

Our results demonstrated that CRP was the only variable which is independently and positively associated with plasma LBP levels $(p=0.001)$. The higher the CRP level the higher the LBP concentrations. Interestingly, Sun et al., observed a stronger correlation between LBP and inflammatory markers after adjustment for BMI. Moreover, adjusting for hs-CRP and IL-6 almost eliminated the associations of LBP with metabolic syndrome and most of its traits. The explaining mechanism is that LBP triggered an immune response involving formation of interleukins and upregulation of CRP synthesis in the liver [10].

After analyzing ROC curves in the current study, using LBP with a cut off of $15.17 \mu \mathrm{g} / \mathrm{mL}$ succeeded to predict both glycemic control and diabetic kidney disease in T2DM patients. This finding could help to predict complications in T2DM patients in our Egyptian population.
Amar et al., reported previously that bacterial $16 S$ rRNA gene blood concentration could predict the onset of diabetes, reporting for the first time the clinical importance of bacterial translocation in the development of T2DM [25]. 16SrRNA is a highly conserved region of bacterial DNA, found in all bacteria; thus by its detection by PCR, all translocated bacteria could be theoretically detected [26]. Ortiz et al., studied DNA translocation in a group of morbidly obese patients candidate for bariatric surgery, they found that inflammatory markers, endotoxin levels, and insulin resistance remained high in patients with bacterial DNA despite weight reduction and were individually affected by the presence or absence of bacterial DNA translocation. They demonstrated increased serum levels of endotoxin in patients with bacterial DNA compared to those without DNA. Moreover, they proved that DNA fragments correspond to commensal gut flora 
and coincide with elevated serum endotoxin levels in those patients [27]. Similarly, Sato et al., found that gut bacteria were detected in blood at a significantly higher rate in diabetic patients than in control subjects, and most of these bacteria were Gram-positive anaerobic bacteria [17]. The findings of the previous studies support our results that bacterial translocation to the blood might play important roles in chronic low-grade inflammation in T2DM and could explain the negative PCR results of glutamine synthase gene of Bacteroides fragilis, or $\beta$-galactosidase gene of $E$. coli.

To further evaluate the role of bacterial translocation on the glycemic control, A French study demonstrated that translocation of commensal bacteria from intestine towards tissue can be reversed with the probiotic strain Bifidobacterium Lactis, which proved to improve the epithelial cell gut barrier, thus reducing bacterial translocation and its consequences on inflammation and insulin sensitivity [28].

While some data on translocation markers and their relationship to chronic inflammation is available for chronic kidney disease patients [29], very little is known about this relationship in T2DM patients. The study conducted by Nymark et al., showed that high serum LPS activity contributes to the development of microalbuminuria and diabetic nephropathy in Finnish patients with type 1 diabetes [11]. Disturbance of gut flora and consequently bacterial translocation and increased inflammatory state, lead to progression of diabetic nephropathy, which might be attributed to the gut-kidney axis in which local renin-angiotensin system is possibly involved [30].

Our study has some limitations. Dietary data and treatment data (insulin, or antidiabetis) were limited. Both could affect gut bacteria and LBP levels as well as DNA translocation. Additionally, we only assessed plasma LBP and not LPS levels. Moreover, the PCR method used in the study simply demonstrates the presence of bacterial DNA, does not specify type of bacteria, and does not differentiate between dead or living microorganisms.

\section{Conclusions}

In conclusion, our study demonstrated that bacterial translocation markers are present at increased levels in patients with T2DM, and are positively correlated with glycemic control, renal and inflammatory markers. They might then trigger diabetes related complications as diabetic kidney disease.

Future research should focus on interventional protocols to investigate whether manipulation of gut microbiota by dietary interventions or by the administration of probiotics could reduce the rate of bacterial translocation. This might decrease systemic inflammatory response and eventually ameliorate glycemic control, and decrease the risk of progression of diabetic kidney disease.

\section{Conflicts of interest}

The authors report no competing interests.

\section{REFERENCES}

1. American Diabetes Association. Standards of medical care in diabetes - 2016. Diabetes Care. 2016; 39: S1-S108.

2. van Olden C, Groen AK, Nieuwdorp M. Role of intestinal microbiome in lipid and glucose metabolism in diabetes mellitus. Clin Ther. 2015; 37(6): 1172-1177, doi: 10.1016/j. clinthera.2015.03.008, indexed in Pubmed: 25922340.

3. Allin $\mathrm{KH}$, Nielsen T, Pedersen O. Mechanisms in endocrinology: gut microbiota in patients with type 2 diabetes mellitus. Eur J Endocrinol. 2015; 172(4): R167-R177, doi: 10.1530/EJE-14-0874, indexed in Pubmed: 25416725.

4. Triantafilou M, Triantafilou K. Lipopolysaccharide recognition: CD14, TLRs and the LPS-activation cluster. Trends Immunol. 2002; 23(6): 301-304, indexed in Pubmed: 12072369

5. Shoelson $\mathrm{SE}$, Lee J, Goldfine $A B$. Inflammation and insulin resistance. J Clin Invest. 2006; 116(7): 1793-1801, doi: 10.1172/ $\mathrm{JCl} 29069$, indexed in Pubmed: 16823477.

6. Schumann RR. Old and new findings on lipopolysaccharidebinding protein: a soluble pattern-recognition molecule. Biochem Soc Trans. 2011; 39(4): 989-993, doi: 10.1042/BST0390989, indexed in Pubmed: 21787335.

7. Liu X, Lu L, Yao P, et al. Lipopolysaccharide binding protein, obesity status and incidence of metabolic syndrome: a prospective study among middle-aged and older Chinese. Diabetologia. 2014; 57(9): 1834-1841, doi: 10.1007/s00125-014-3288-7, indexed in Pubmed: 24906952.

8. Tilves CM, Zmuda JM, Kuipers AL, et al. Association of lipopolysaccharide-binding protein with aging-related adiposity change and prediabetes among african ancestry men. Diabetes Care. 2016; 39(3): 385-391, doi: 10.2337/dc15-1777, indexed in Pubmed: 26721818.

9. Moreno-Navarrete JM, Ortega F, Serino $M$, et al. Circulating lipopolysaccharide-binding protein (LBP) as a marker of obesity-related insulin resistance. Int J Obes (Lond). 2012; 36(11): 1442-1449, doi: 10.1038/ijo.2011.256, indexed in Pubmed: 22184060.

10. Sun L, Yu Z, Ye X, et al. A marker of endotoxemia is associated with obesity and related metabolic disorders in apparently healthy Chinese. Diabetes Care. 2010; 33(9): 1925-1932, doi: 10.2337/ dc10-0340, indexed in Pubmed: 20530747.

11. Nymark M, Pussinen PJ, Tuomainen AM, et al. FinnDiane Study Group. Serum lipopolysaccharide activity is associated with the progression of kidney disease in finnish patients with type 1 diabetes. Diabetes Care. 2009; 32(9): 1689-1693, doi: 10.2337/ dc09-0467, indexed in Pubmed: 19502539.

12. The Expert Committee on the Diagnosis and Classification of DM. Report of the Expert Committee on the Diagnosis and Classification of DM. Diabetes Care. 2003; 10: 1183-1197.

13. Singh B, Saxena A. Surrogate markers of insulin resistance: A review. World J Diabetes. 2010; 1(2): 36-47, doi: 10.4239/wjd. v1.i2.36, indexed in Pubmed: 21537426.

14. Kidney Disease: Improving Global Outcomes (KDIGO) CKD Work group. KDIGO 2012 Clinical Practice Guideline for the Evaluation and Management of Chronic Kidney Disease. Kidney Inter Suppl. 2013; 3:1-150.

15. Kane TD, Alexander JW, Johannigman JA. The detection of microbial DNA in the blood: a sensitive method for diagnosing 
bacteremia and/or bacterial translocation in surgical patients. Ann Surg. 1998; 227(1): 1-9, indexed in Pubmed: 9445103.

16. Ganz ML, Wintfeld N, Li Q, et al. The association of body mass index with the risk of type 2 diabetes: a case-control study nested in an electronic health records system in the United States. Diabetol Metab Syndr. 2014; 6(1): 50, doi: 10.1186/1758-5996-6-50, indexed in Pubmed: 24694251.

17. Sato J, Kanazawa A, Ikeda F, et al. Gut dysbiosis and detection of "live gut bacteria" in blood of Japanese patients with type 2 diabetes. Diabetes Care. 2014; 37(8): 2343-2350, doi: 10.2337/ dc13-2817, indexed in Pubmed: 24824547.

18. Herder C, Illig T, Rathmann W, et al. KORA Study Group. Inflammation and type 2 diabetes: results from KORA Augsburg. Gesundheitswesen. 2005; 67 Suppl 1: S115-S121, doi: 10.1055/s2005-858252, indexed in Pubmed: 16032528.

19. Cox AJ, Zhang P, Bowden DW, et al. Increased intestinal permeability as a risk factor for type 2 diabetes. Diabetes Metab. 2017; 43(2): 163-166, doi: 10.1016/j.diabet.2016.09.004, indexed in Pubmed: 27745826

20. Gubern C, López-Bermejo A, Biarnés J, et al. Natural antibiotics and insulin sensitivity: the role of bactericidal/permeabilityincreasing protein. Diabetes. 2006; 55(1): 216-224, indexed in Pubmed: 16380496

21. Zhou H, Hu J, Zhu Q, et al. Lipopolysaccharide-binding protein cannot independently predict type 2 diabetes mellitus: A nested case-control study. J Diabetes. 2016; 8(2): 214-219, doi: 10.1111/1753-0407.12281, indexed in Pubmed: 25753130.

22. Kim KE, Cho YS, Baek KS, et al. Lipopolysaccharide-binding protein plasma levels as a biomarker of obesity-related insulin resistance in adolescents. Korean J Pediatr. 2016; 59(5): 231-238, doi: 10.3345/ kjp.2016.59.5.231, indexed in Pubmed: 27279888.

23. Sakura T, Morioka T, Shioi A, et al. Lipopolysaccharide-binding protein is associated with arterial stiffness in patients with type 2 diabetes: a cross-sectional study. Cardiovasc Diabetol. 2017; 16(1): 62, doi: 10.1186/s12933-017-0545-3, indexed in Pubmed: 28486964.

24. Trøseid M, Nestvold TK, Rudi K, et al. Plasma lipopolysaccharide is closely associated with glycemic control and abdominal obesity: evidence from bariatric surgery. Diabetes Care. 2013; 36(11): 3627-3632, doi: 10.2337/dc13-0451, indexed in Pubmed: 23835694.

25. Amar J, Serino M, Lange C, et al. D.E.S.I.R. Study Group. Involvement of tissue bacteria in the onset of diabetes in humans: evidence for a concept. Diabetologia. 2011; 54(12): 3055-3061, doi: 10.1007/s00125-011-2329-8, indexed in Pubmed: 21976140.

26. Mai V, Morris JG. Colonic bacterial flora: changing understandings in the molecular age. J Nutr. 2004; 134(2): 459-464, doi: 10.1093/ jn/134.2.459, indexed in Pubmed: 14747689.

27. Ortiz S, Zapater P, Estrada JL, et al. Bacterial DNA translocation holds increased insulin resistance and systemic inflammatory levels in morbid obese patients. J Clin Endocrinol Metab. 2014; 99(7): 2575-2583, doi: 10.1210/jc.2013-4483, indexed in Pubmed: 24735424.

28. Amar J, Chabo C, Waget A, et al. Intestinal mucosal adherence and translocation of commensal bacteria at the early onset of type 2 diabetes: molecular mechanisms and probiotic treatment. EMBO Mol Med. 2011; 3(9): 559-572, doi: 10.1002/emmm.201100159, indexed in Pubmed: 21735552.

29. Wang $F$, Jiang $H$, Shi $K$, et al. Gut bacterial translocation is associated with microinflammation in end-stage renal disease patients. Nephrology (Carlton). 2012; 17(8): 733-738, doi: 10.1111/j.14401797.2012.01647.x, indexed in Pubmed: 22817644.

30. Lu CC, Ma KL, Ruan XZ, et al. Intestinal dysbiosis activates renal renin-angiotensin system contributing to incipient diabetic nephropathy. Int J Med Sci. 2018; 15(8): 816-822, doi: 10.7150/ ijms.25543, indexed in Pubmed: 30008592. 